

Available online at www.jlls.org

JOURNAL OF LANGUAGE

AND LINGUISTIC STUDIES

ISSN: $1305-578 \mathrm{X}$

Journal of Language and Linguistic Studies, 17(4), 1888-1906; 2021

\title{
Auxiliary verbs in Jordanian Arabic
}

\author{
Ayman Rashad Yasin a ${ }^{\text {ID }}$, Ibtisam Hussein ${ }^{\text {b }}$ iD \\ a Princess Sumava Universitv for Technology, Jordan \\ ${ }^{b}$ Philadelphia University, Jordan
}

\begin{abstract}
APA Citation: $10.52462 / j 11 s .137$

Submission Date:20/04/2021

Acceptance Date:19/07/2021
\end{abstract}

Yasin, A.R., \& Hussein, I. (2021). Auxiliary verbs in Jordanian Arabic. Journal of Language and Linguistic Studies, 17(4), 1888-1906. Doi:

\begin{abstract}
There are a number of helping verbs in Jordanian Arabic that are confused with light verbs or serial verbs. This paper, first, establishes the criteria on which they have been identified as auxiliary verbs. The paper shows the similarities and differences between the inflection of lexical verbs and AUX's in JA. It also tackles the loss of $\theta$ assigning properties which is the crucial property that differentiates between AUX and lexical and serial verbs. Second, given the fact that Arabic has rich verbal morphology which provides enough justification for factoring TP into TP and AspP (and perhaps AgrP), the study adopts an articulated version of the IP, in which inflection is separated into its constituent components, each has a maximal functional projection. The study also builds on Ouhalla's proposal $(1990,2005)$ that auxiliaries originate outside the VP shell. Based on evidence from the distribution of VP adverbs, negation and floating quantifiers, the paper proposes that auxiliaries in Jordanian Arabic are classified under two lexical auxiliary groups. T-aux are borne in a functional projection under $\mathrm{T}$, but raise to $\mathrm{T}^{0}$ to carry and reflect tense, while Asp-aux are base-generated under $\mathrm{Asp}^{0}$ and only raise to $\mathrm{T}$ in the absence of a T-Aux.
\end{abstract}

Keywords: Jordanian Arabic; auxiliary verb; Tense; Aspect; inflection; agreement.

\section{Introduction}

Rivero (1994) has argued for partitioning of auxiliaries into lexical and functional on the basis of presence or lack of lexical content, selectional properties, and phonological properties. Krapova (1997) adopted the same criteria. However, she did not consider 'lexical content' a sufficient condition for determining the status of the auxiliary as lexical or functional.

In the simplest form, when a verb helps another verb to form one of its tenses in a sentence, such verb can be said to be auxiliary (Akintoye 2018). Auxiliaries have many syntactic and semantic functions. Aguirre and Aquirre (2019) list several uses for auxiliary verbs in Japanese: expressing past tense, aspectual continuative forms, desire, hypothetical propositions, and passive voice. In Turkish, some auxiliary verbs are used in compound verb structures formed of $\mathrm{N}+\mathrm{V}$ (Arici, 2019). Mardar (2018) pinpoints that auxiliary verbs have the same grammatical function irrespective of the language.

\footnotetext{
1 Corresponding author.

E-mail address: a.yasin@psut.edu.jo
} 
To prove that certain semantic features are shared by the auxiliary verbs, Madar studied relevant formal and semantic similarities and differences between the most common auxiliary verbs in English, Romanian and Italian.

As for JA, the paper argues that JA auxiliaries are lexical because of certain properties that will be discussed throughout this paper. Lexical auxiliaries in Jordanian Arabic (JA) are borne out under VP (before they move up) since they have the same position in the clause as lexical verbs have in a clause without an auxiliary verb. They also carry the same inflection and agreement markings that a lexical verb can carry. The paper argues that these are indeed auxiliaries rather than serial or light verbs. Given the fact that all these auxiliaries have been grammaticalized by JA, as well as most Arabic dialects, this study seeks first to establish the criteria on which these auxiliaries have been identified and, second, give evidence for their syntactic projections.

Three syntactic structures have been proposed for auxiliaries: the VP complement analysis (Chomsky, 1988; Guéron \& Hoekstra, 1988; Moore, 1991 for complex predicates; Pollock, 1989 for French auxiliaries), a verbal complex analysis (Emonds 1978 for French), or a 'flat' VP analysis (Abeille \& Godard, 2002; Legaré \& Rollin, 1976). This paper adopts the VP complement analysis and hence uses the tests that such an analysis had used.

This paper is organized as follows: section 2 presents our proposal. Section 3 presents the preliminary properties of lexical auxiliaries that make them distinct from serial or light verb. Section 4 presents some evidence for the positions of the two lexical AUX groups. Section 5 concludes

\section{The Proposal}

There are two groups of lexical auxiliaries in JA: T-aux, which can raise to $\mathrm{T}^{0}$, and Asp-aux which encode aspectual information (progressive, terminative, prospective, etc.) For clarity, these groups will be dubbed as T-AUX, and Asp-AUX). The study focuses on the distinction between kaan and gafad as representatives of the two groups. The preliminary properties for each of these AUX's are set to become a basis for building the argument for the structural projections of each groups. Expletives, Tto-C movement, and non-verbal predicates are used as tests in the case of the first group. Adverbials lend some evidence for the syntactic projections of the second group.

Below is a table of the auxiliary verbs under each group along with the functions and lexical meanings they carry:

Table 1. AuX's Functional and Lexical Meanings

\begin{tabular}{|c|c|c|c|}
\hline GROUP & AUX & Functions & Lexical Meaning \\
\hline T-AUX & $\begin{array}{l}\text { kaan } \\
\text { ðəl } \\
\text { baga } \\
\text { saar }\end{array}$ & $\begin{array}{l}\text { Past tense } \\
\text { progressive/habitual } \\
\text { durative and continuative } \\
\text { progressive/ habitual } \\
\text { change of a state }\end{array}$ & $\begin{array}{l}\text { be } \\
\text { stay } \\
\text { survive, stay } \\
\text { become }\end{array}$ \\
\hline Asp-AUX & $\begin{array}{l}\text { gaSad/ga:Yid/ } \\
\text { balla } \\
\text { garrab } \\
\text { batṭal } \\
\text { ija }\end{array}$ & $\begin{array}{l}\text { inchoative \& progressive } \\
\text { inchoative } \\
\text { prospective } \\
\text { terminative }\end{array}$ & $\begin{array}{l}\text { sit down } \\
\text { start } \\
\text { become close to } \\
\text { stop }\end{array}$ \\
\hline
\end{tabular}




\begin{tabular}{|l|l|l|l|}
\hline & $\begin{array}{l}\text { bigdar } \\
\text { riji3 }\end{array}$ & initiation & come \\
ability/permission & can \\
resumption & come back \\
\hline
\end{tabular}

It is important to mention that these categories have been classified according to their functions (mentioned in table 1 above) and according to their positions in relation to each other as shown in (1) below ${ }^{2}$.

a. Kaan

\section{Be:pst-3sm Omar PART-sit ${ }^{3}$}

$\begin{array}{ll}\text { Omar } & \text { ga:Gid } \\ \text { Omar } & \text { PART-sit }\end{array}$

yi-drus

3-IMPF-study ingli:zi la-S-Subih

English to-the-morning

'Omar had the habit of studying English until daybreak'
*b. $\quad \operatorname{gaCad}$
Omar y-kuun
yi-drus
ingli:zi la-S-Subih
sit:pst-3sm
Omar 3:impf-be
3-IMPF-study
English to-the-morning

'Omar had the habit of studying English until daybreak'

Sentences (1.a \&b) make it clear that kaan must precede ga:Sid. In section (4), we will show where each of these categories is generated and where it can move.

While both T-aux and Asp-aux share some aspectual properties, it is worth mentioning that they differ with their selection of complement types as T-aux can occur with verbal and non-verbal predicate, while Asp-aux selects only verbal predicates as shown in examples (2\&3).
a. Omar
kaan
[y-naam
Omar
T-aux:PST:3SM
IMPF:3SM-sleep
'Omar used to sleep in the library'
b. Omar
kaan
Omar
T-aux:PST:3SM
$[\text { ustaaz }]_{\mathrm{NP}} /[\text { naayem }]_{\mathrm{AP}}$
a teacher / asleep

fi-l-maktabe-h] $\underline{\text { vp }}$

in-the-library

'Omar was a teacher / asleep / in the library'
a. Omar
gaSad
[yi-drus
fi-l-maktabe-h] $]_{\mathrm{VP}}$
Omar
PROG AUX : PRF:3SM
[IMPF:3SM-study
in-the-library]

'Omar got in the process of studying in the library'
b. Omar
gaSad
Omar
sit: PRF:3SM
*[ustaaz $]_{\mathrm{NP}} / *[\text { naayem }]_{\text {AdjP }}$
a teacher / asleep

'Omar sat *a teacher / *asleep'

\section{Literature Review}

In this section, we will review literature related to the inflectional and derivational similarity between L-aux and lexical verbs. On the other hand, we will also go over some studies that established properties that make AUX's different from serial, and light verbs. First, section 3.1 shows the similarity between the inflection of lexical verbs and AUX's in JA. The next section addresses some

\footnotetext{
${ }^{2}$ The following abbreviation are used throughout the paper: $\mathrm{PRF}=$ perfective, IMPF $=$ imperfective, $\mathrm{IMP}=$ imperative, PART: active participle, $1,2,3=$ person, $\mathrm{M}=$ masculine, $\mathrm{F}=$ feminine, $\mathrm{S}=$ singular, $\mathrm{PL}=$ plural, $\mathrm{AUX}=$ auxiliary, COMP $=$ complementizer, $\mathrm{IND}=$ indicative, SUBJ=subjunctive, JUSS=jussive.

${ }^{3}$ The active participle gqGid is used in the same fashion as the auxiliary gaYad. So, we will use them interchangeably.
} 
morphological differences between them. In 3.3, we present the functional meanings for auxiliary verbs and their lexical counterparts. 3.4 tackles the loss of $\theta$-assigning properties which is the crucial property that differentiates between AUX and lexical and serial verbs. The last section addresses the differences between these AUX groups in terms of type of complement each group takes and the aspectual selection of the complement.

\subsection{Studies related to AUX Inflection}

A number of researchers have been interested in the inflection of auxiliary verbs and tried to related and compare that to the inflection of lexical verbs. Milicevic (2010) pinpoints that auxiliaries express values of verbal semantic inflectional variables (mood and tense) and carry syntactic inflectional values. L-Aux in JA can carry inflectional morphology: T-AUX and Asp-AUX inflect for person, number, and gender. They also inflect for the three verb forms in Arabic (IMPF, PRF, and IMP). Examples (4) \& (5) below show the similarity between lexical verbs and T- AUX, Asp- AUX in terms of inflection.

$$
\begin{array}{llll}
\text { int-i } & \text { fakkar-ti } & \text { bi-1-imtiћaan } & \text { imbaareh } \\
\text { 2-sf } & \text { think:PRF-2sf } & \text { about-the-exam } & \text { yesterday }
\end{array}
$$

'You(f) thought about the exam yesterday'

$$
\begin{array}{llll}
\text { int-i } & \text { kun-ti / } \quad \text { gafad } \text {-ti } & \text { t- fakkr-i } & \text { bi-1-imtiћaan } \\
\text { 2-SF } & \text { T-aux:PST-2SF/ Asp-aux:PRF-2SF } & \text { IMPF :2S -think-F } & \text { about-the-exam }
\end{array}
$$

'You(f) were/ started and were in the process of thinking about the exam'

Note that in (4-5) above the AUX and the lexical verb both carry the same $\varphi$-features. Moreover, JA auxiliaries behave like lexical verbs with respect to NegP elements as shown in the following examples:

$$
\begin{array}{ll}
\text { a. } & \text { Omar ma-kaani- } \int \\
\text { Omar NEG-be:3SM:PAST-NEG }
\end{array}
$$

$\begin{array}{ll}\text { y-drus } & \text { kwayyes } \\ \text { IMPF:3SM-study } & \text { well }\end{array}$

'Omar did not use to study well'

$$
\begin{array}{ll}
\text { b. Omar ma-daras- } \int \\
\text { Omar NEG-study:3SM-NEG }
\end{array}
$$

kwayyes

well

'Omar did not study well'

It is this similarity in inflection that calls for dubbing them as L-aux ${ }^{4}$. It is also this similarity that made other researchers think of these auxiliaries as light or serial verbs (Hussein 1990, Pallottino 2018, Alotaibi, 2019). First, auxiliaries, light verbs and serial verbs share the following: same subject, same tense and mood, negation is marked on the first element, the two verbs are not separated by intonational or clause boundary, both verbs express one event. However, while serial verbs come from an open class, light and auxiliary verbs come from a restricted class. Additionally, serial verbs do not express tense or aspectuality. On the other hand, while light verbs come from certain semantic sets (e.g posture, motion), auxiliary verbs are grammaticalized and therefore are semantically bleached. More importantly, serial or light verbs can stand on their own in independent clauses due to their semantic content. Auxiliaries, by contrast, cannot serve as lexical verbs unless they are given their semantic content before they have been grammaticalized (7a):

\footnotetext{
${ }^{4}$ Aoun, Banmamoun and Choueiri (2010) identified only three auxiliaries in Lebanese Arabic; kaan 'be', rəh

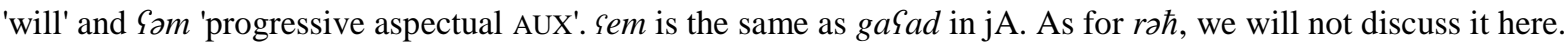


(7)

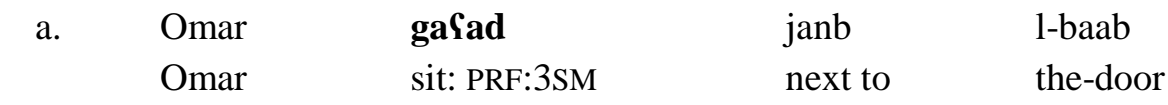

'Omar sat next to the door'
b. Omar
gaSad
yi-tfarraj
Ga-t-telfizion
Omar
Asp-AUX: PRF:3SM
IMPF:3SM-watch
on-the-TV

'Omar was watching TV'

\subsection{Morphological Derivation}

Auxiliaries are morphologically indistinguishable from other verbs in Arabic; in particular, they bear inflectional affixes just like lexical verbs (example 6 above). Nonetheless, AUX's differ from lexical and serial verbs with respect to derivational morphology. For instance, nouns can be derived from lexical and serial verbs but not from AUX's. Thus, from the lexical verb y-zoor 'to visit' an equivalent noun ziyaarah 'a visit' can be derived. By contrast, there are no noun forms for the AUX'S 'ðəl, gaSad, baga, bigdar, kaan, saar, ballash, jaay: come',etc. If they were serial or light verbs, we would expect them to have a nominal derivative.

(8)

$\begin{array}{ll} & \text { zaar } \\ & \text { visit:PRF:3SM } \\ \text { a. } & \text { ठəl } \\ & \text { keep:PRF:3SM } \\ \text { b. } & \text { ija } \\ & \text { come:PRF:3SM }\end{array}$

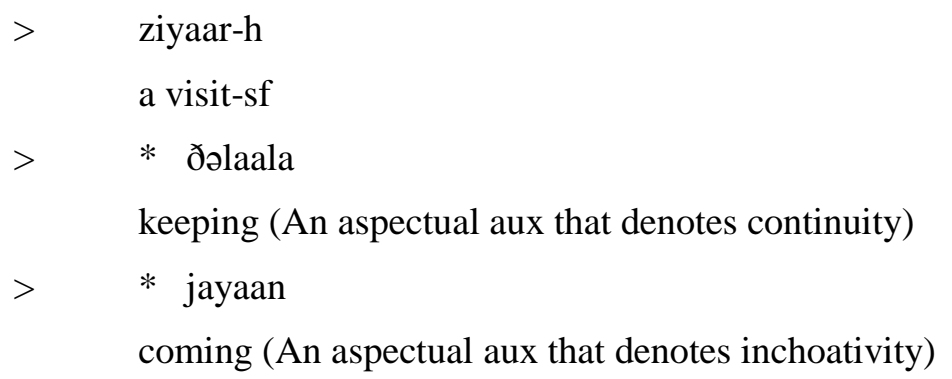

Another morphological difference concerns transitivity/ causativity: a process that adds an additional argument to the root, making intransitive verbs transitive, or transitive ones ditransitive. The most common way of doing this in Arabic is by geminating the middle consonant (compare 10a \& 10b and 11a \&11b). AUX's, by contrast, cannot undergo this process since they cannot assign $\theta$-roles in the first place.
a. Omar
$\underline{\mathrm{ma} a}$
la-d-dukkan
Omar
walk: PRF:3SM
to-the-store

'Omar walked to the store'

$\begin{array}{llll}\text { b. } & \text { Ahmed } & \text { Omar } & \text { la-d-dukkan } \\ \text { Ahmed } & \text { walk:CAUS: PRF:3SM } & \text { Omar } & \text { to-the-store }\end{array}$

'Ahmed walked Omar to the store'
a. Omar
Jirib
Omar
drink: PRF:3SM
d-dawa
the-medicine

'Omar swallowed the medicine'

\begin{tabular}{|c|c|c|}
\hline $\begin{array}{l}\text { Ahmed } \\
\text { Ahmed }\end{array}$ & 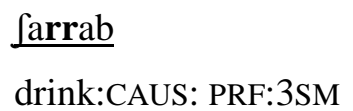 & $\begin{array}{l}\text { Omar } \\
\text { Omar }\end{array}$ \\
\hline
\end{tabular}

'Ahmed made Omar swallow the medicine'

In (10a) above, the predicate mafa 'walk' is an intransitive verb in Arabic and thus takes only one argument. By contrast, in (10b), the predicate maffa is transitive, roughly 'to cause/force to walk' and so adds another argument to the event structure, the agent Ahmed. By the same token, in (11a) the verb 
firib is transitive. By geminating the middle consonant, it becomes ditransitive, hence the verb takes three (italicized) arguments in (11b). Given its function, the germination serves as a light verb. This, in fact, excludes the idea that L-aux in JA are light verbs because we can add an aux before the geminated verb. In other words, L-aux is borne in a position higher than vP.
Ahmed qaSad
$y-\underline{m a \int j i}$
Omar
la-d-dukkan
Ahmed
ASP-CONT:3SM
walk:CAUS: PRF:3SM
Omar
to-the-store

'Ahmed was in the action of making Omar walk to the store'

AUX's, on the other hand, cannot undergo such morphological alternation as the ungrammaticality of (13b) shows.
a. et -țullaab
gaYad-u
y-ktub-u
ed-dars
the-student:PL Asp-AUX: PRF -3PL
3SM:IMPF-write-PL
the-lesson

'the students were in the process of writing the lesson.'
b. * el-ostaaz
gaY̧ad
et -ṭullaab
y-ktub-u
The teacher:m
Asp-AUX:CAUS: PRF:3SM
the-student:PL
3SM:IMPF-write-PL
ed-dars
the-lesson

Intended: 'The teacher made the students start and continue the process of writing the lesson.

Again, if gaSad is a serial or light verb, it would have accepted transitivity/ causativity as the first verb in a serial verb behaves like in other verb in the language.

\subsection{Reviewing Functional vs Lexical Meaning}

AUX consists of a collection of elements which can be characterized notionally as tense, modality, and aspect (Akmajian, Steele \& Wasow, 1979, 1). Bridges $(2008,27)$ defines AUX verbs as "grammaticalized forms of main verbs that encode various non-lexical information in a predicate; usually tense, aspect or mood". Generally speaking, auxiliary definitions relate AUX verbs to their lexical counterparts. Lots of languages have this type of alternation - lexical verbs vs. 'bleached/aspectual' light verbs. Specifically, auxiliaries differ from lexical and light verbs in that they do not denote a state-of-affairs or event. Heine (1993) distinguishes four parameters that characterize the degree of grammaticalization of lexical verbs into auxiliary verbs: semantic (desemanticization), morphosyntactic (decategorialization), morphophonological (cliticization), and phonetic shift (erosion). Semantically, some auxiliaries in JA have retained some of the meaning of their lexical verb counterparts. In other words, they are not completely bleached. Morphophonogically, T-aux and Aspaux are inflected and conjugated like lexical verbs, but they do not exhibits phonetic shift. For these reasons, traditional Arab grammarians (e.g Al-Farahidi, 718-786 AD; Sibawayh, 760-797 AD) have treated these linguistic entities ${ }^{5}$ as defective verbs. Supposing that the category AUX covers a continuum, JA L-auxiliaries will fall close to lexical verbs.

However, syntactically, these auxiliaries differ from lexical verbs in that they are tense-aspect markers, and thus have a functional meaning rather than a lexical one. Therefore, they need to be projected outide the VP shell (Alexiadou, 1997; Haegeman, 1994; Ouhalla, 1991; Rohrbacher 1999).

\footnotetext{
5 Traditional Arab grammarians recognized only T-AUX and labeled them as kaan wa Paxawaatuha 'be and its sisters'. The group contained 12 defective verbs, but only four as used in JA nowadays.
} 
As we said before, what makes AUX verbs in JA and in Arabic in general distinct from auxiliaries in other languages is the fact that they resemble lexical verbs in inflection. On the other hand, they are also distinctive because they cover a wide range of aspectual, tense and mood functions. This, in fact, makes these verbs auxiliaries rather than serial or light verbs because although serial and light verbs may also carry tense and/or aspect, they have semantic content.

\subsection{Loss of $\Theta$-Assigning Properties}

Perhaps the most important distinction between AUX's and lexical verbs is that the latter can assign $\theta$-roles to their arguments (internal as well as external). Goossens (1985) contends that the difference between independent (lexical) verbs and auxiliaries is related to whether AUX brings along its argument structure, in which case it is taken as an independent verb, or whether a combining predicate imposes its argument structure on the whole combination. Therefore, in order to be used as auxiliaries, these verbs must be used in a specific grammatical function, such as tense or aspect. Such grammaticalization results in losing the ability to assign $\theta$-roles.

Comparing the lexical verb ballas in (14) to its functional counterparts in (15a-c), we conclude that ballaf as a lexical verb assigns an internal $\theta$-role to fuвиl 'work, job' and an external one to Omar. However, as an AUX balla cannot assign $\theta$-roles. For instance, Omar is assigned a $\theta$-role of an agent 'a player' in (15a) from the main verb $y$-lSab 'play', an experiencer 'feeler' in (15b) from the lexical verb $y$-S $\mathcal{S} u r$ 'feel', and in (15c) no $\theta$-role is assigned to the null dummy pronoun in the subject position.
a. Omar balla
e $\int-\int$ иииl
1 -jdeed
gabl youm-ein
Omar start:3SM:PRF the-work/job the-new
before day-DUAL

'Omar started/ took up the new job two days ago'
a.
Omar ballaf
$\mathrm{y}-19 \mathrm{ab}$
fatbol
Omar Asp-aux:3sM: PRF
IMPF:3SM-play
soccer

'Omar started playing football'
b. Omar ballaf

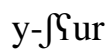
bi-?idei-h
Omar Asp-aux:3SM: PRF
IMPF:3SM-feel
with-hands-his

'Omar started feeling his hands, i.e. not numbed'
c.
[ pro
balla $\int$-at
Asp-aux: PRF -3SF
t-mațtiir
IMPR:3SF-rain

'(it) started raining'

In brief, auxiliaries are basically functional elements which differ from lexical verbs in that they lack a thematic grid, the property which accounts for their inability to assign arguments. In addition, auxiliaries are not members of the argument structure of lexical verbs in the sense that they do not bear any thematic relation to the lexical verb or any of its arguments and therefore should be excluded from VP.

However, it could be argued that 'ballash' in (15) is a serial verb as argued by Pallotino (2018) for the verb bdit in MA which has the same meaning as ballash. This claim is ruled out on the grounds that in serial verbs negation is always marked on the first verb in the string and applies to the whole string. However, in (15b), for example, we can negate the first or the second verb with a clear difference in meaning:

$$
\begin{array}{lll}
\text { a. Omar ma balla } \\
\text { Omar Neg Asp-aux:3SM: PRF }
\end{array}
$$

'Omar has not started feeling his hands yet'
b.
$\begin{array}{lll}\text { Omar balla } & \text { ma } \\ \text { Omar } & \text { Asp-aux:3SM: PRF } & \text { neg }\end{array}$

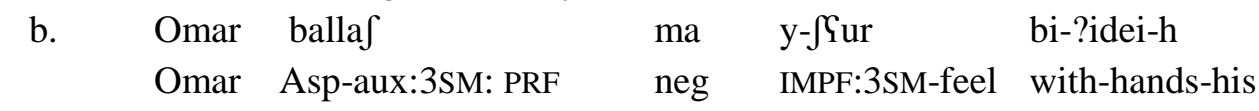
y-STur bi-?idei-h
IMPF:3SM-feel with-hands-his


'Omar started not feeling his hands, i.e. they became numb'

\subsection{Complement Type and Aspect Subcategorization:}

The last distinction between lexical and L-auxiliary verbs involves the type of complement each takes. On one hand, as argued in many studies, different auxiliaries take different aspectual subcategorization. Generally speaking, the three groups of JA AUX select IMPF aspect in their complement. However, some select PRF form as well. First, all T-AUX's take IMPF aspectual verb complements except for the copula kaan which can take PRF aspect as well.
a. Omar kaan/ ðəl
yi-19ab
fi-1-jim
Omar kaan:PST:3SM/keep:PST:3SM
IMPF :3SM-play
in-the-gym

'Omar was playing/ kept playing in the gym'

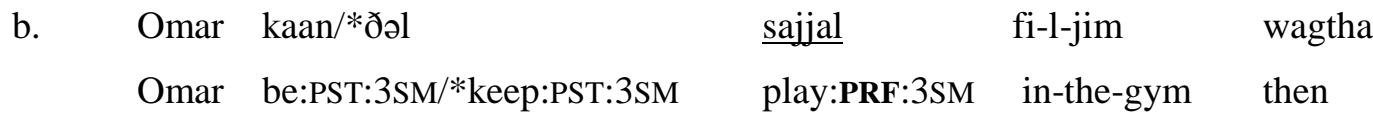

'Omar had/*kept signed up in the gym then'

Second, Asp-AUX subcategorize only for IMPF verb complement.

$\begin{array}{llll}\text { Omar } & \text { gaYad } & \text { yi-1Yab/*li@ib } & \text { fi-1-jim } \\ \text { Omar } & \text { PROG AUX : PRF:3SM } & \text { IMPF :3SM-play/*play:PRF:3SM } & \text { in-the gym }\end{array}$

'Omar was playing in the gym'

Since some of these auxiliaries can select IMPF or PRF aspectual verb, this indicates that they are not serial or light verbs which subcategorize one form of the verb (usually IMPF aspectual verb).

\section{Discussion}

Having presented the basic properties for JA AUX, the study moves on to prove the syntactic position for each of the two AUX groups. In this section, we present the background assumptions that will be adopted in the analyses to follow. Given the fact that Arabic has rich verbal morphology which provides enough justification for factoring TP into TP and AspP (and perhaps AgrP), the study follows Belletti (1994); Carnie (2007); Chomsky (2001); Haegeman and Gueron (2005); Hornstein et al. (2010); Pollock (1989); Radford (2004) in adopting an articulated version of the IP, in which inflection is separated into its constituent components, each has a maximal functional projection (FP). The study also adopts Ouhalla's proposal $(1990,2005)$ that auxiliaries originate outside VP.

Having worked mainly on English and French, Pollock (1989) presented several tests to show whether a verb raises to a functional projection or remains in situ. These tests include negation, aspectual adverbs, stranded quantifiers, and T-to-C movement. Notably, these classical tests have been commonly used by generativists (see Carnie, 2008; Haegeman and Gueron, 2005; Hornstein et al., 2010; Ouhalla, 2005; Radford, 2004 to name few). Building our arguments on these tests, the study reveals a number of syntactic differences between the three types of auxiliaries that have so far remained unnoticed by the traditional accounts. It will be shown that T-AUX enter the structure under a functional head (AspP due to their aspectual meaning) and end up under T, whereas Asp-AUX are base-generated under AspP and raise to $\mathrm{T}$ in the absence of a T-AUX.

\subsection{T-AUX}

The first group of L-AUX'S in JA is the T-AUX which include (kaan 'be, habitual and progressive', baga 'habitual and progressive', Saar 'change of state' and ðal 'durative continuative'). Cuvalay (1994) 
pointed out that the complex forms of kaan + the lexical verb represent one syntactic unit, consisting of a predicate (the lexical verb) and an auxiliary, where kaan puts the main proposition in the past while the lexical predicate specifies an aspectual value. Cuvalay adds that although most of these verbs (kaan and its sisters, which amount to T-AUX in JA) can function as full verbs, their most common use is incomplete, in the sense they occur in complex constructions with another verb or with a nonverbal predicate. As such, their lexical meaning is reduced or empty. Here, the study will shed light on the functional projection that these AUX occupy. We argue that T-AUX start as Asp ${ }^{0}$ and then raise to $\mathrm{T}^{0}$ as in (19).

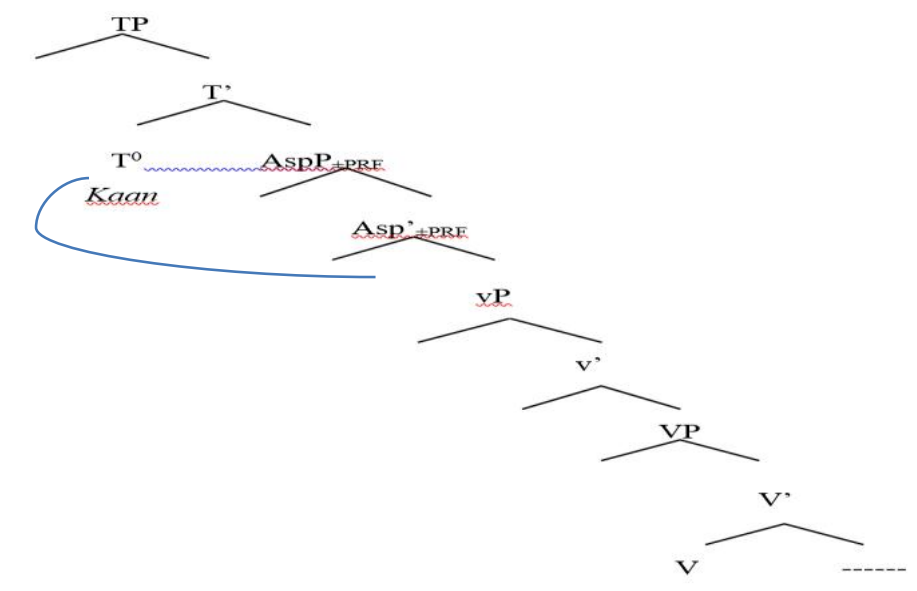

Figure 1. T-AUX starting in $\mathrm{Asp}^{0}$ and raising to $\mathrm{T}^{0}$

The first piece of evidence comes from expletives which are content-free elements that are licensed by a functional category, particularly $\mathrm{T}^{0}$. In JA the expletive fii 'there' occurs only with T-AUX.

$$
\begin{aligned}
& \text { a. fii } \\
& \text { kaan } \\
& \text { kalb } \quad y \text {-Sawwi } \\
& \text { fi-1-hara }
\end{aligned}
$$

'There was a dog barking in the vicinity'

$\begin{array}{lllll}\text { b. } & \text { kaan } & \text { fii } & \text { kalb } & \text { y-Sawwi fi-1-ћara } \\ & \text { T-AUX:3SM:PAST } & \text { there } & \text { a dog } & \text { IMPF:3SM-bark in-the-vicinity' }\end{array}$

'There was a dog barking in the vicinity'

Based on the assumption of Aoun et al. (2009); Carnie (2008); Chomsky (1988); Haegeman (1994); Hornstein et al. (2010); Ouhalla (1990); and Radford (2004), it is predicted that such an expletive is licensed by $\mathrm{T}^{0}$. In (20a), kaan starts in AspP then raises to $\mathrm{T}^{0}$. In (20b), on the other hand, kaan has undergone further movement, perhaps to AgrS which appears right above TP (Chomsky, 1988; Haegeman, 1994; Hornstein et al., 2010; Ouhalla, 1990, 2005; Pollock, 1989).

By contrast, gaSad, an Asp- AUX, cannot co-occur with the expletive fii, although both kaan \& gaSad indicate progressiveness in that same context. The ungrammaticality of (21) indicates that the AUX gaSad cannot license the expletive fii. This, in turn, suggests that gaSad cannot raise to $\mathrm{T}^{0}$.

$$
\begin{array}{lllll}
* \text { fii } & \text { gaSad } & \text { kalb } & \text { y-Yawwi } & \text { fi-1-hara } \\
\text { There } & \text { ASP-AUX:3SM: PRF } & \text { a dog } & \text { IMPF:3SM-bark } & \text { in-the-vicinity' }
\end{array}
$$

'There was a dog barking in the vicinity'

Moreover, if we assume that kaan is raised to $\mathrm{T}^{0}$, we predict that $\mathrm{T}^{0}$ raises to $\mathrm{C}^{0}$ when making questions in neutral contexts. This movement is triggered by a $[+Q]$ feature in $\mathrm{C}^{0}$. According to Head 
Movement Constraint (Travis, 1984), and Relativized Minimality (Rizzi1990, 2004; and Rizzi and Cinque, 2008), the movement between one head position and another is only possible between a head of a given structure and the head of its complement. Therefore, if an element moves to the head $\mathrm{C}^{0}$, then it must have been in the head position of its complement TP, i.e. T-to-C movement as seen in (22):
a. Omar
kaan
$\mathrm{y}-1 \mathrm{Cab}$
Jaddi-h
Omar
T-AUX:3SM:PST
IMPF:3SM-play
cards-f

'Omar was playing cards'

$\begin{array}{llcl}\text { b. } \quad\left[\text { ср еi } \int_{\mathrm{k}}\right. & \text { kaan }_{\mathrm{i}} & \text { [тр Omar } \mathrm{t}_{\mathrm{i}} & \mathrm{y}-1 \mathrm{Cab} \\ \text { what } & \text { T-aux:3SM:PST } & \text { Omar } & \text { IMPF:3SM-play? }\end{array}$

'What was Omar playing?'
c. $\quad\left[\begin{array}{lll}\text { cP } & \text { ei } \int_{\mathrm{k}} & \mathrm{C}^{0}\end{array}\right.$
kaan $_{\mathrm{i}}$
$\left[\operatorname{TP~т~}^{0} t_{i} \quad\right.$ [vP $\quad$ Omar $\quad y-19 a b$
$\mathrm{t}_{\mathrm{k}}$ ?]]
what
T-aux:3SM:PST
Omar
IMPF:3SM-play?

'What was Omar playing?'

(22a) above is a declarative sentence that has a T-AUX kaan. (22b-c) are WH-questions in which the WH-word eish raises from the object position $\left(\mathrm{t}_{\mathrm{k}}\right)$ to [Spec/CP]. Since JA allows SVO and VSO orders, there are two possibilities: According to the SVO order, one can assume that kaan has raised from $\mathrm{T}^{0}$ to $\mathrm{C}^{0}$ leaving a trace and that Omar remains in [Spec/TP] as in (22b). However, on the VSO account, it can be assumed that Omar was in [Spec/vP] or even in [Spec/AspP], and kaan was in $\mathrm{T}^{0}$ (and may have moved toAgrS $\mathrm{S}^{0}$ ) and then moved to $\mathrm{C}^{0}$ but the movement is vacuous since we still have the same order before movement, as shown in (22c).

Moreover, if we find an element that must appear between $\mathrm{T}$ and $\mathrm{C}$, then we can prove that (22b-c) is on the right track, i.e kaan raises from $\mathrm{T}$ to $\mathrm{C}$ :

$$
\begin{array}{llll}
\text { wala-hada } & \text { kaan } & \text { y-lYab } & \text { Jaddi-h } \\
\text { nobody } & \text { T-aux:3SM:PST } & \text { IMPF:3SM-play } & \text { cards-f }
\end{array}
$$

'Nobody was playing cards'

Negative elements like wala-ћada 'nobody' are obligatorily moved to [Spec/TP]. If that negative element appears after kaan in questions, then kaan raises to $\mathrm{C}^{0}$ :

$$
\begin{array}{lllll}
\text { a. } & \text { Eif } & \text { kaan } & \text { wala-hada } & \text { y-1Sab? } \\
& \text { What } & \text { T-aux:3SM:PST } & \text { nobody } & \text { IMPF:3SM-play }
\end{array}
$$

'What was nobody playing?'

$\begin{array}{llll}\text { b. } & \text { *Eish wala-hada } & \text { kaan } & \text { y-1Sab? } \\ & \text { What nobody } & \text { T-aux:3SM:PST } & \text { IMPF:3SM-play }\end{array}$

'What was nobody playing?'

The data in (24a-b) supports our claim that kaan raises to $\mathrm{C}^{0}$. Applying (Head Movement Constraint (HMC), the T-AUX kaan must have raised to $\mathrm{T}^{0}$ before it raises to $\mathrm{C}^{0}$. 
(25)

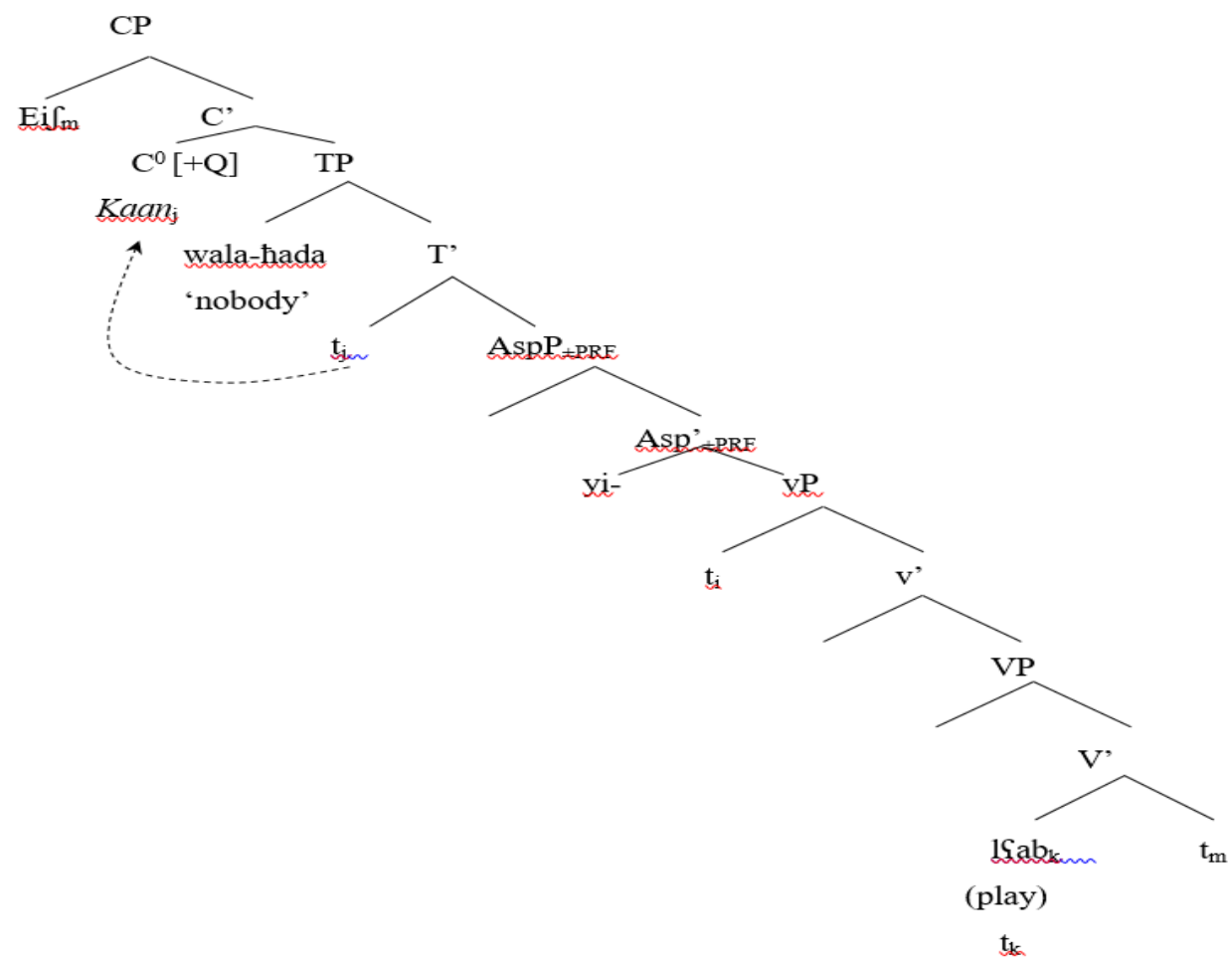

Figure 2. T-AUX raising to $\mathrm{T}^{0}$ before raising to $\mathrm{C}^{0}$

In addition, the fact that we cannot have a doubly filled Comp in JA as shown by (26b) proves that kaan must occupy the functional head below $\mathrm{C}^{0}$, i.e, $\mathrm{T}^{0}$.
a. ba-Staqid
inno Omar kaan
$\mathrm{y}-1 \mathrm{Gab}$
Jaddi-h
IMPF:1S-think
Comp Omar T-AUX:3SM:PST
IMPF:3SM-play
cards-f

'I think that Omar was playing cards'
b. *ba-Staqid
inno kaan
Omar y-19ab
Jaddi-h
IMPF: 1S-think
Comp T-AUX:3SM:PST
Omar IMPF:3SM-play
cards-f

'I think that Omar was playing cards'

A final piece of evidence for the argument that T-AUX raise to $\mathrm{T}^{0}$ comes from sentences with nonverbal predicates ${ }^{6}$. The implication that the sentences in question have a $\mathrm{T}$ with a present tense feature even though their predicate is a nominal phrase is widely supported by the fact that they are compatible with present tense adverbs but not with past and future tense adverbs (Ouhalla, 1991). The temporal category present time reference is not necessarily expressed, but past and future tense in most Arabic dialects are (Cuvalay, 1994). Benmamoun (2000) proposed that a verbless sentence has a functional projection that has a null copula in $\mathrm{T}^{0}$ since it does not have a verbal predicate:

$$
\begin{array}{llll}
\text { Omar } & \text { [ тр Т } \varnothing & \text { ustaaz } & \text { haaliyyan } \\
\text { Omar } & & \text { a teacher } & \text { at the mean time }
\end{array}
$$

'Omar is a teacher at the mean time'

\footnotetext{
${ }^{6}$ Some linguists call such sentences verbless sentences (Benmamoun, 2000 \&Fassi Fehri, 1993), some dub them as nominal sentences (Abulhaija, 1989 \& Jaradaat, 2007) among others.
} 
However, in the past all T-AUX can be inserted in the same place as the null copula in (28), before the predicate. This, in turn, indicates that these AUX occupy the same $\mathrm{T}^{0}$ position.
Omar
[ тр T kaan/baga/ șaar/
ðəl
ustaaz]
Omar
T-aux:3SM:PST
a teacher

'Omar was, was, became, remained a teacher'

By contrast, Asp- AUX cannot be inserted in that position as shown by the ungrammatical sentence in (29). This implies that Asp- AUX cannot raise to $\mathrm{T}^{0}$.

$\begin{array}{rll}* \text { Omar } & \text { gafad } & \text { ustaaz } \\ \text { Omar } & \text { Asp-aux:PRF:3sm } & \text { a teacher }\end{array}$

'Omar was a teacher'

\subsection{Asp-AuX in Asp ${ }^{0}$}

We have seen in the previous section that T-AUX can raise to $\mathrm{T}^{0}$. That was supported by three pieces of evidence: licensing of expletive in [Spec/TP] by a T-AUX, T-to-C movement, and the appearance of T-AUX group in $\mathrm{T}^{0}$ in the past of a non-verbal sentence where a null copula appears in $\mathrm{T}^{0}$ in the present. It was also shown that Asp-AUX cannot license expletives nor can they surface in the past of a non-verbal sentence indicating that these AUX do not raise to $\mathrm{T}^{0}$.

On the one hand, "The existence of a fixed word order among AUX provides an initial argument in favor of the claim that they are heads rather than adjuncts" (Cole, 2008, p.113). The fixed order indicates that these auxiliaries occupy different positions. Consider, for instance, the following example where kaan and gaSad appear in a fixed order.
a.
El-awlaad
kaan-u
y- hill-u
el-waajib
The -boys
T-AUX:PST-3PL
IMPF -do-3PL the-homework

'The boys were doing their homework'
b. El-awlaad
kaan-u
yi-gSud-u
$\mathrm{y}-$ hill-u
el-waajib
The boys
T-AUX:PST-3PL IMPR-Asp-AUX-3PL
IMPF -do-3PL
the-HW

'The boys used to get in the process of doing their homework'

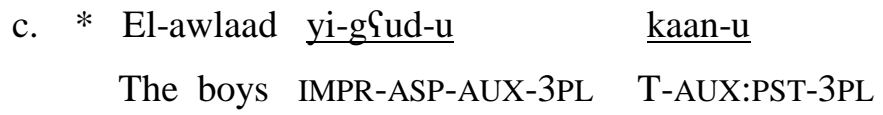

$$
\begin{array}{ll}
\text { y- ћill-u } & \text { el-waajib } \\
\text { IMPF -do-3PL } & \text { the-HW }
\end{array}
$$

'The boys used to get in the process of doing their homework'

Fronting of one head, gaYad, over kaan, is ruled out by HMC (Travis, 1984). Since we have already shown that kaan raises to $\mathrm{T}^{0}$, and we can assume that the lexical verb is in $\mathrm{V}$, then there must be at least another head and projection between them. Let's assume that is the projection that gaSad occupies. Given its aspectual denotation, and following Edmonds' analysis (1978) of the temporal aspectual verbs, gaYad is assumed to be an Asp head. A T-AUX, then, can take either an Asp-AUX or a lexical verb as its complement. By contrast, an Asp-AUX only takes a lexical verb as its complement. No other ordering among the AUX is possible since any other order would violate the strict complement subcategorizations. 
(31)

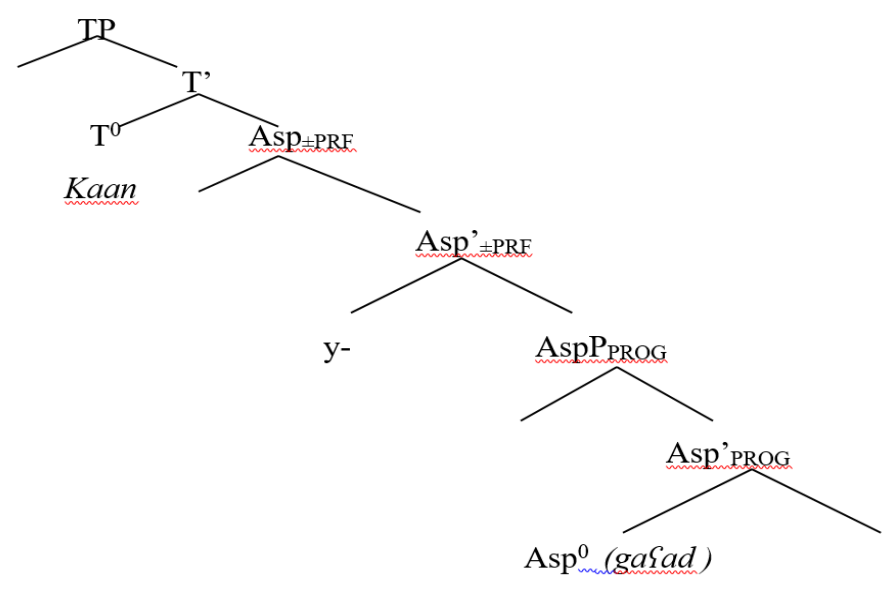

Figure 3. Strict order of T-aux and Asp-aux

Additionally, the fact that a VP adverb occurs after kaan but before gaSad when they co-occur supports our argument that the former is in $\mathrm{T}^{0}$ and the latter is in $\mathrm{Asp}^{0}$.
a. Omar kaan
raliban
yi-g乌ud
* saliban
Omar T-AUX:3SM:PAST
often
IMPF:3sm-Asp-AUX
often

$$
\begin{array}{ll}
\text { yi-drus } & \text { fi-1-maktabeh } \\
\text { IMPF:3sm-study } & \text { in-the-library }
\end{array}
$$

'Omar often used to get in the process of studying in the library'

In the remaining of this section, we are going to examine whether Asp- AUX's raise to $T^{0}$ in the absence of a T-AUX, and whether or not they raise to other aspectual projections.

\subsubsection{Asp-AUX Raising to $T^{0}$}

We saw that when a T-AUX co-occurs with an Asp-AUX, the former occupies $\mathrm{T}^{0}$, whereas the latter is in $\mathrm{Asp}^{0}$. However, the AUX gaSad in $\mathrm{Asp}^{0}$ can appear without kaan in $\mathrm{T}^{0}$. Compare (33a) and (33b)
a. Omar kaan
ga:Gid
yi-drus
ingli:zi
Omar T-AUX:PST:3SM
Asp-AUX:PRF:3SM
IMPF :3SM-study
English
Sindma
wṣil-na
when
arrive:PRF-1PL

'Omar had already got in the process of studying English when we arrived'
b. Omar gaSad
yi-drus
ingli:zi
Gindma wṣil-na
Omar Asp-AUX: PRF:3SM
IMPF :3SM-study English
when arrive:PST-1PL

'Omar started and was in the in the process of studying English when we arrived'

In these cases, the question arises: does gąad (a) raise to $\mathrm{T}^{0}$ or (b) remain in situ? 
(34)

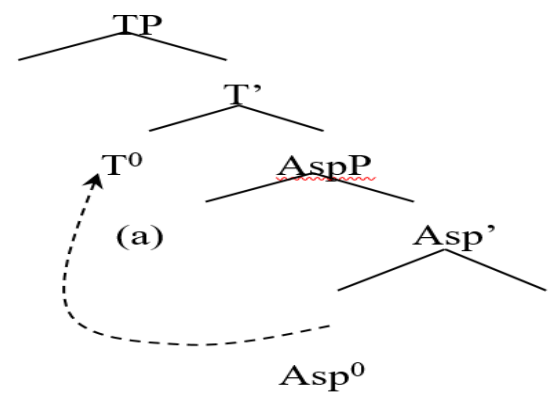

(b)

Figure 4. Asp-aux raising to $\mathrm{T}^{0}$

According to Cinque (2003), the sentence is divided into different zones: "the higher CP zone represents distinctions in clause typing and informational structure, a lower zone that presents evaluative, evidential and epistemic operators and comprises tense, aspect, modal and voice, and even a lower zone that contains the lexical verb, the arguments and additional participant adjuncts." AUX are located between CP and VP as we saw earlier and V is born in the lowest zone (but this does not tell us whether or not the verb raises from the lowest level to the intermediate level to catch the aspectual or tense markers). Since we are trying to find out whether the Asp-AUX raises or not, we will use the adverb mubafaratan 'instantly' which is related to aspect- denoting the beginning of the event-and thus is adjoined to such an aspectual projection.

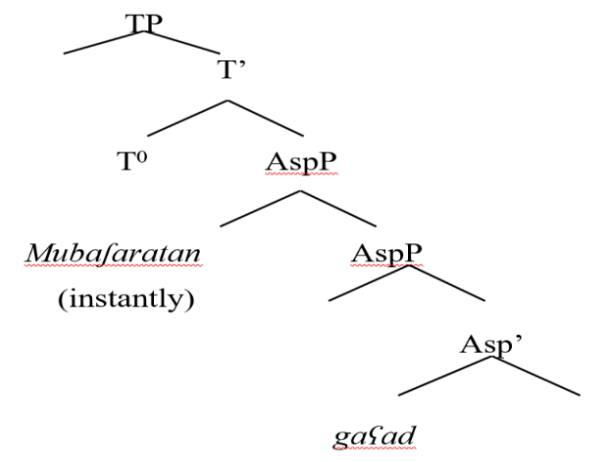

Figure 5. Asp-aux in relation to an aspectual adverb

If gaSad - the Asp-AUX- appears before the adverb, this indicates that Asp-AUX raises to $\mathrm{T}^{0}$ in the absence of a T-AUX. Otherwise, Asp-AUX remains in Asp ${ }^{0}$.

$$
\begin{aligned}
& \text { a. Omar gafad mubafaratan } \\
& \text { Omar Asp-AUX: PRF:3SM instantly }
\end{aligned}
$$$$
\text { yi-drus ingli:zi }
$$$$
\text { IMPF :3SM-study English }
$$

'Omar had instantly got in the process of studying English'
b. Omar mubafaratan
gaSad
Omar instantly
Asp-AUX:PRF:3SM
yi-drus
ingli:zi
IMPF:3SM-study English

'Omar had instantly got in the process of studying English' 7

\footnotetext{
7 (36b) can be rendered grammatical when the adverb is focused. However, when that happens the focused element is marked by an emphatic stress and/or a pause after it.
} 
The example in (36a) confirms that gaSad raises to $\mathrm{T}^{0}$ since the adverb is located after it. Since (36b) is also acceptable, this indicates that $\mathrm{ga} S a d$ can also remain in Asp ${ }^{0}$. Further evidence for AspAUX raising to $\mathrm{T}$ comes from $\mathrm{T}$-to-C movement: If AUX has the option of raising to $\mathrm{T}$, they can further raise to C in accordance with Relativized Minimality (Rizzi, 1990, 2004; Rizzi and Cinque, 2008). In this respect, Asp-AUX in JA behave like English auxiliaries.

Can John read that book?
a. $\quad \mathrm{gaYad}$
Omar yidrus
fi-1-maktabeh imbaareh?
Asp-AUX:3SM Omar IMPF :3SM-study
in-the-library yesterday?

'Did Omar get in the process of studying in the library yesterday?'
b. $\quad *$ Omar
gaSad
yidrus
fi-l-maktabeh imbaareh?
Omar
Asp-AUX:3sM
IMPF :3SM-study
in-the-library yesterday?

'Did Omar get in the process of studying in the library yesterday?'

Second, as the case with T-AUX, when C is filled, gaSad cannot raise to C:
a. ba-Staqid
inno Omar gaSad
$y-19 a b$
Jaddi-h
IMPF:1 S-think
Comp Omar Asp-AuX:3sm
IMPF:3SM-play
cards-f

'I think that Omar was playing cards'
b. *ba-Staqid
inno gaYad
Omar $\mathrm{y}-19 \mathrm{ab}$
Jaddih
IMPF:1S-think
Comp Asp-AUX:3sm
Omar IMPF:3SM-play cards

'I think that Omar was playing cards'

There remains one more point related to the lexical verb. Besides the AUX gaSad, the progressive aspect can also be expressed by the aspectual prefix $b i$ - which attaches to lexical verbs ${ }^{8}$. "In Colloquial Egyptian Arabic, the preverbal markr $b i$ - expresses progressive or habitual aspect. The preverbal $h a$ - is used to indicate prospective aspect or future tense. In most Moroccan dialects, the preverbal $\mathrm{ka}$ - (or $\mathrm{ta}$ ) and gadi- (ga) cover more or less the same values" (Cuvalay 1994, p.4).

If there is a T-AUX like kaan, and the progressiveness of the event is meant, kaan can be followed by either $g a A_{a d}$ or by the prefix $b i-$, but not both:
a. Omar kaan
yi-gGud
Omar T-AUX:PST:3SM
IMPF-Asp-AUX:3SM
ingli:zi
la-ș-ṣubiH
English
to-the-morning

'Omar used to get in the process of studying English to the day light'
b. Omar kaan
$\varnothing \quad$ b-yi-drus
ingli:zi la-ṣ-ṣubiH
Omar T-AUX:PST:3SM
ASP-IMPF :3SM-study
English to-the-morning

'Omar was studying (past-HAB/PROG) English to the day light'

Both gaSad and $b i$ - occur between kaan and the lexical verb, and both denote progressive aspect. Let us assume that in (41) below, kaan is in $\mathrm{T}^{0}$ and the aspectual prefix $b i$ - is in $\operatorname{Asp}^{0}$ under $\mathrm{T}^{0}$.

\footnotetext{
${ }^{8}$ One difference between $g a a_{a d}$ and the prefix $b i$ - is that gaSad incorporates both progressive and inchoative aspects, whereas $b i$ - only indicates the progressive aspect.
} 
(41)

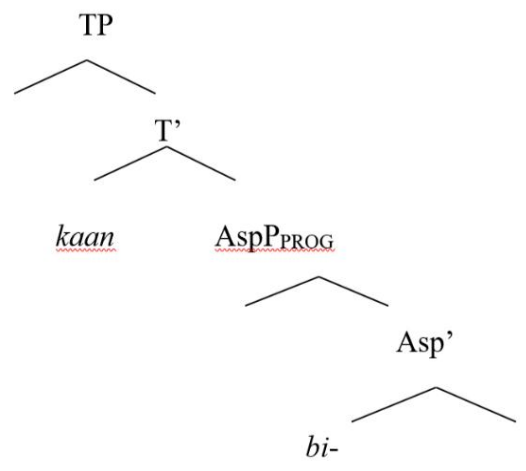

Figure 6. T-aux kaan in $\mathrm{T}^{0}$ and the aspectual prefix $b i$ - in $\mathrm{Asp}^{0}$ under $\mathrm{T}^{0}$

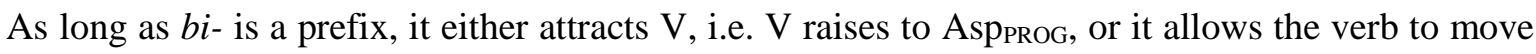
through it to a higher position.

\section{Conclusion}

This paper presented criteria for distinguishing AUX in JA from lexical, serial and light verbs. The paper also showed that there are two AUX groups that have different complement type and aspect subcategorization. T-AUX and Asp-AUX take a projection of VP complement generally in the IMPF form except for kaan which can also take a PRF complement. The paper also proposed that T-AUX, Asp-AUX carry different syntactic and morphological properties. On par with previous studies, (e.g. McCarthy, 1993; Rivero 1994; Krapova 1997; Kohle, 2000), T-AUX and Asp-AUX are roughly lexical auxiliaries. The two groups occupy different positions in the structure. Specifically, T-AUX can raise to $\mathrm{T}^{0}$, Asp-AUX are located in $\mathrm{Asp}^{0}$. Syntactic evidence for the position of the T-AUX came from expletives, T-to-C movement and non-verbal predicate sentences. Adverbs were used as a test to show the syntactic heads that Asp-AUX can occupy: Asp-AUX raise to $\mathrm{T}^{0}$ only if $\mathrm{T}^{0}$ is not already filled by a T-AUX.

\section{References}

Abeillé, A., \& Godard, D. (2002). The syntactic structure of French auxiliaries. Language, 404-452.

Abulhaja, L. (1989). The development of negative structures in children: Evidence from Jordanian Arabic. Arab Journal for Humanities, 36, 343-372.

Aguirre, S., \& Aguiar, J. (2019, July). A Japanese Word Segmentation Proposal. In Proceedings of the 57th Annual Meeting of the Association for Computational Linguistics: Student Research Workshop (pp. 429-435).

Akintoye, F.A. (2018). A Comparative Study of French and English Auxiliary Verbs. IJOHMN (International Journal online of Humanities), 4(4), 21-21.

Akmajian, A., Steele, S. M., \& Wasow, T. (1979). The category AUX in universal grammar. Linguistic inquiry, 10(1), 1-64.

Alexiadou, A. (1997). Adverb placement: A case study in antisymmetric syntax (Vol. 18). John Benjamins Publishing. 
Al-Farahidi, A. (1981). Al-Sayn. Revised by Mahdi Al-Makhzumi, and Ibrahim Al-Samirra'i. Iraq: Dar Al-Rashid Publishers.

Aoun, J. E., Benmamoun, E., \& Choueiri, L. (2009). The syntax of Arabic. Cambridge University Press.

Aoun, J., Choueiri, L., \& Hornstein, N. (2001). Resumption, movement, and derivational economy. Linguistic inquiry, 32(3), 371-403.

Arici, F. (2019). Fuzulî’nin Türkçe Divani’ndaki Et-(İt-) Ve Kil-Yardimci Fiilleri İle Kurulan Birleşik Fiiller. Turkish Studies, 14(3), 1057-1075.

Benmamoun, E. (2000). The feature structure of functional categories: A comparative study of Arabic dialects. New York: Oxford University Press.

Boskovič, Z. (2009). On unvalued uninterpretable features. University of Connecticut.

Bridges, M. (2008). Auxiliary verbs in Uyghur. PhD Thesis. University of Kansas

Carnie, A. (2008). Syntax: A generative introduction. Blackwell Publishing.

Chomsky, N. (1988). Notes on economy of derivation and representation. MIT WPL, 10, 43-75.

Chomsky, N. (2001). Derivation by Phase. In M. Kenstowicz Kane (Ed.), A life in Language. (pp.152). Cambridge, MASS: MIT Press.

Cinque, G. (2003). Issues in adverbial syntax. Linguistics, 13, 31-71.

Cole, P., Hara, Y. \& Yap, N. (2008). Auxiliary fronting in Peranakan Javanese. Linguistics 44. Cambridge University Press.

Cuvalay, M. (1994). Auxiliary verbs in Arabic. In Engberg-Pedersen, Falster Jakobsen, Schack Rasmussen (Eds), Function and expression in functional grammar (pp. 265-283). Berlin and New York: Mouton de Gruyter.

Emonds, J. (1978). The verbal complex V'-V. Linguistic Inquiry, 9, 151-175.

Fassi-Fehri, A. (1993). Issues in Arabic clauses and words. Dordrecht: Kluwer Academic Publishers.

Goossens, L. (1985). The auxiliarization of the English modals: A functional grammar view. Working Papers in Functional Grammar 7.

Haegeman, L. (1994). Introduction to government and binding theory. Oxford: Blackwell.

Haegeman, L. and Gueron J. (2005). English Grammar. Blackwell Publishing.

Heine, B. (1993). Auxiliaries: Cognitive force and grammaticalization. Oxord: Oxord University Press.

Hornstein, N., Nunes, J \& Grohmann, K. (2010). Understanding minimalism. Cambridge University Press.

Krapova, I. (1997). Auxiliaries and complex tense in Bulgarian. In W. Browne, E. Dornisch, N. Kondrasova and D. Zec (Eds.). Formal approaches to Slavic linguistics. The Cornell Meeting (pp. 320-344). Ann Arbor: Michigan Slavic Publications.

Mardar, A. M. (2018). A Comparative-Contrastive Approach to Auxiliary Verbs in English, Romanian and Italian. Analele Universității" Dunărea de Jos din Galați, Lexic comun/Lexic specializat, 1(19), 156-164. 
McCarthy, J. (1993). A case of surface constraint violation. Canadian Journal of Linguistics, 38(2), 169-195.

Moore, J. (1991). Reduced constructions in Spanish. Santa Cruz: University of California,

Ouhalla, J. (1990). Sentential negation, relativised minimality and the aspectual status of auxiliaries. The Linguistic Review, 7, 183-231.

Ouhalla, J. (1991). Functional categories and Parametric variation. London: Routledge.

Ouhalla, J. (1993). Negation, focus and tense: The Arabic maa and laa. Revista di Linguistica 5, 275300.

Ouhalla, J. (2005). Agreement features: Agreement and antiagreement. Natural Language and Linguistic Theory, 23, 655-686.

Öz, S. (2019). Özbekçede Kiliniş Işslemcisi Olarak Yardimci Fiiller (Master's Thesis, Sosyal Bilimler Enstitüsü).

Pollock, J. (1989). Verb Movement, Universal Grammar, and the Structure of IP. Linguistic Inquiry. 20 (3), 365-424

Radford, A. (2004). Minimalist syntax. Cambridge Univesity Presss.

Rivero, M. (1994). Clause structure and verb movement in the languages of the Balkans. Natural Language and Linguistic Theory, 12(1), 63-120.

Rizzi, L. \& Cinque, G. (2008). The cartography of syntactic structure. Studies in Linguistics. CISCL Working Paper, 2, 42-58.

Rizzi, L. (1990). Relativized Minimality. Cambridge: MIT Press.

Rizzi, L. (1997). The fine structure of the left periphery. In L. Haegeman (Ed.), Elements of Grammar (pp. 281-337). Kluwer: Dordrecht.

Rizzi, L. (2004). Locality and left periphery. In Belletti, (Ed.), Structure and beyond: The cartography of syntactic structure (pp. 223-251). New York: Oxford University Press.

Rohrbacher, B. (1999). Morphology-driven syntax: A theory of $V$ to I raising and prosodic drop. Amsterdam: John Benjamin.

Travis, L. (1984). Parameters and effects of word order variation. PhD Dissertation, MIT.

\section{AUTHOR BIODATA}

Dr. Ayman Yasin is currently the head of the Coordination Unit for Service Courses at Princess Sumaya University for Technology in Jordan. He studied linguistics at Purdue University in Indiana, USA (2008-2012). $\mathrm{He}$ is interested in social sciences in general and in linguistics in particular. He has published a number of papers in syntax, phonology, translation, and prosody. Dr. Yasin has also taught MA and PhD courses in linguistics and translation at the University of Jordan (part timer). He is supervisor and an external examiner for many MA and $\mathrm{PhD}$ theses in various Jordanian universities. He has experience in IELTS tests and he serves as a reviewer in several journals.

Ibtisam Hussein Jamil Mohammad is an associate professor in phonetics and phonology and the director of the Language Center at Philadelphia University in Jordan. She has been teaching several BA and MA courses in the Arabic Departments in Isra' University, Middle East University and Philadelphia University in Jordan. She also supervised many MA and PhD theses. Dr. Mohammad is interested in acoustic phonetics and phonology, discourse analysis, syntax, Arabic as a foreign language, and morphology. She participates in various cultural 
activities in different academic institutions. She launched 'Philadelphia for Knowledge' initiative which focuses on increasing the Arabic scientific and knowledge content on the internet. She published hundreds of original and translated articles on the initiative website and she carried out a number of cultural events that serve Arabic regionally and internationally. 